\section{PENGARUH TOTAL QUALITY MANAGEMENT DAN KEADILAN PROSEDURAL (PROCEDURAL JUSTICE) TERHADAP KINERJA KARYAWAN DI PT. LAMONGAN GAS LESTARI KABUPATEN LAMONGAN}

\author{
Miftahul Huda \\ Moh. Azus Shony Azar \\ Fakultas Ekonomi Universitas Islam Darul 'Ulum Lamongan \\ miftahulhuda@unisda.ac.id \\ azus@unisda.ac.id
}

\begin{abstract}
Human resources are important in a company Therefore, it is necessary to have good human resource management to support the achievement of the objectives of the company by implementing Total Quality Management and Procedural Fairness to employees. This research to determine and analyze how much Total Quality Management and Procedural Fairness on Employee Performance. The sampling technique used is field research using saturated samples. The samples of this study were 34 samples, employees who worked at PT. Lamongan Gas Lestari Lamongan Regency which then becomes the respondent and fills in the questionnaire provided by the author. Based on questionnaire data that has been processed with the help of the SPSS 23.0 application and has been tested for validity and reliability, it can be stated that all of the data is valid and reliable. Then based on the results of the study show based on the F test states that there is an effect of Total Quality Management, Procedural Justice simultaneously on employee performance of 30,660, t test stated that the variable Total Quality Management of 2.952 and Procedural Justice of 3.420 is the dominant variable in influencing employee performance. Based on the coefficient of determination test it can be seen that the R2 value of 66.4 means that the influence of Total Quality Management, Procedural Justice and employee performance is $66.4 \%$, the remaining $33.6 \%$ is influenced by other factors outside this research variable.
\end{abstract}

Keywords: Total Quality Management, Procedural Justice and employee performance

Abstrak: Sumber daya manusia merupakan hal penting dalam suatu perusahaan Maka dari itu, perlu adanya manajemen sumber daya manusia yang baik untuk mendukung tercapainya tujuan dari perusahaan dengan cara menerapkan Total Quality Management dan Keadilan Prosedural terhadap karyawan. Penelitian ini bertujuan untuk mengetahui dan menganilasa seberapa besar Total Quality Management dan Keadilan Prosedural terhadap Kinerja karyawan.Teknik pengambilan sampel yang digunakan adalah penelitian lapangan dengan menggunakan sampel jenuh. Adapun Sampel dari penelitian ini adalah 34 sampel, karyawan yang bekerja di PT. Lamongan Gas Lestari Kabupaten Lamongan yang kemudian dijadikan responden dan mengisi lembar kuesioner yang telah disediakan penulis. Berdasarkan data kuesioner yang telah diolah dengan bantuan aplikasi SPSS 23.0 dan telah melalui uji validitas dan reabilitas dapat dinyatakan seluruh data tersebut valid dan realibel. Lalu berdasarkan Hasil penelitian menunjukkan berdasarkan uji F menyatakan bahwa terdapat pengaruh Total Quality Management ,Keadilan Prosedural secara simultan terhadap Kinerja karyawan sebesar 30,660 , Uji t menyatakan bahwa variabel Total Quality Management sebesar 2,952 dan Keadilan Prosedural sebesar 3,420 adalah variabel yang dominan dalam mempengaruhi Kinerja karyawan. Berdasarkan uji koefisien determinasi dapat diketahui bahwa nilai R2 sebesar 66,4 artinya pengaruh Total Quality Management ,Keadilan Prosedural dan kinerja karyawan sebesar 66,4\%, sisanya sebesar 33,6\% dipengaruhi oleh faktor lain diluar variabel penelitian ini.

Kata Kunci: Total Quality Management, Keadilan Prosedural dan kinerja karyawan 


\section{PENDAHULUAN}

Dalam roda organisasi merupakan suatu kesatuan kerja yang di dalamnya terdapat berbagai individu yang memiliki latar belakang dan tipikal yang berbeda-beda dan saling bekerjasama untuk mencapai tujuan organisasi. Tercapai atau tidaknya suatu tujuan dan target organisasi sangat dipengaruhi oleh kinerja SDM yang ada di dalam organisasi tersebut. Seperti halnya dengan instansi pemerintah yang merupakan sebuah contoh organisasi dimana proses seluruh anggota di dalam organisasi tersebut harus solid dalam bekerjasama untuk mencapai tujuan organisasi atau instansi.

Keberhasilan suatu target dan ekspektasi organisasi atau instansi sangat ditentukan oleh salah satunya adalah kinerja para karyawannya dalam seluruh bidang-bidangnya. Fungsi dan peran karyawan dalam setiap usaha merupakan faktor yang penting.Oleh karena itu, perusahaan atau instansi harus mampu mengolah dan mengelola sumber daya manusia dengan baik mungkin dan sesuai aturan instansi sehingga terjadi keseimbangan dan keselarasan terhadap seluruh karyawan baik dalam bidang maupun lintas bidang yang ada dalam sebuah instansi tersebut.Untuk itu dalam pelaksanaannya, sebuah organisasi memerlukan suatu teknis akurat dalam manajerial, salah satunya adalah Total Quality Management (TQM).

Menurut Ishikawa, Total Quality Management (TQM) diartikan sebagai perpaduan semua fungsi dari suatu perusahaan ke dalam falsafah holistis yang dibangun berdasarkan konsep kualitas, teamwork, produktivitas, dan pengertian serta kepuasan pelanggan (Ishikawa dalam Hadi, 2014:2). Definisi lainnya menyatakan bahwa TQM merupakan sistem manajemen yang mengangkat kualitas sebagai strategi usaha pada kepuasan pelanggan dengan melibatkan seluruh anggota organisasi.TotalQuality Management (TQM) dapat dibedakan menjadi dua aspek. Aspek pertama menguraikan apa yang dimaksud dengan TQM ialah suatu pendekatan dalam menjalankan usaha yang mencoba memaksimumkan daya saing organisasi melalui perbaikan terus menerus atas produk, jasa, tenaga kerja, proses dan lingkungannya. Kemudian aspek kedua membahas bagaimana mencapainya (Tjiptono dalam Hadi, 2014: 3 )

Dalam penelitian yang akan dilakukan peneliti memfokuskan hanya pada keadilan prosedural. Keadilan prosedural adalah keadilan organisasi yang berhubungan dengan prosedur pengambilan keputusan oleh organisasi yang ditunjukkan kepada karyawannya (Hidayah dan Haryani dalam Widiastuti, 2016: 89).

Keadilan harus terwujud di semua lini kehidupan, dan setiap produk manusia haruslah mengandung nilai-nilai keadilan, karena sejatinya perilaku dan produk yang tidak adil akan menimbulkan ketidakseimbangan, ketidakserasian yang berakibat kerusakan baik dalam diri manusia maupun semesta (Aburaera dkk, 2003: 177).

Menurut Nurcholis Madjid dalam NDP HMI (Solichin, 2010:259) Kualitas terpenting yang harus dipunyainya, ialah rasa kemanusiaan yang tinggi sebagai pancaran kecintaan yang tak terbatas pada Tuhan. Di samping itu diperlukan kecakapan yang cukup.Kelompok orang-orang itu adalah pimpinan masyarakat; atau setidak-tidaknya mereka adalah orang-orang yang seharusnya memimpin masyarakat. Memimpin adalah menegakkan keadilan, menjaga agar setiap orang memperoleh hak asasinya, dan dalam jangka waktu yang sama menghormati kemerdekaan orang lain dan martabat kemanusiaannya sebagai manifestasi kesadarannya akan tanggung jawab social.

Organisasi dapat memperoleh manfaat nyata dari evaluasi kinerja,termasuk pengetahuan tentang karyawan yang berkinerja sangat baikdan sangat jelek sehingga bagi karyawan tersebut dapat diberi balasjasa yang adil (Kirana dan Ratnasari, 2017: 27).

Keberhasilan jangka panjang suatu organisasi ataupun perusahaan tergantung pada kemampuan kinerja karyawannya, pengukuran kinerja dan menggunakan informasi hasil pengukuran tersebut sebagai dasar melakukan usaha-usaha perbaikan kinerja agar dapat sesuai dengan tingkat standar dan ketentuan yang telah ditetapkan dan tuntutan perubahan lingkungan usaha.

PT. Lamongan Gas Lestari yang beralamat J1. Raya Gembong No.1, Dusun Bulu Trate, Desa Sumurgenuk, Kecamatan 
Babat, Kabupaten Lamongan, Jawa Timur Dalam peningkatan kinerja karyawan dituntut untuk melakukan tugasnya dengan baik, dan dalam hal tersebut berkaitan dengan penerapan Total Quality Management (TQM) merupakan suatupendekatan yang mencoba untuk memaksimumkan daya kerja karyawan melalui pendidikan terus menerus atas sumber daya manusia dan perbaikan lingkungannya merupakan salah satu yang diperlukan dalam instansi dan system keadilan Prosedural yang harus di terapkan manajemen agar mendapatkan kepercayaan karyawan sehingga karyawan punya motivasi untuk meningkatkan kinerja karyawan di dalam perusahaan.

Menyadari akan pentingnyaTotal Quality Management (TQM) dan keadilan prosedural terhadap kinerja karyawan, maka penulis tertarik untuk melakukan penelitiandengan judul "Pengaruh Total Quality Management Dan Keadilan Prosedural (Procedural justice) Terhadap Kinerja Karyawan Di PT. Lamongan Gas Lestari Kabupaten Lamongan"

\section{PERUMUSAN MASALAH}

Berdasarkan latar belakang dapat dirumuskan masalah sebagai berikut :
1. Apakah
Total
Quality

Managementberpengaruh terhadap Kinerja

Karyawan PT. Lamongan Gas Lestari

Kabupaten Lamongan?

2. Apakah Keadilan Prosedural (Procedural justice) berpengaruh terhadap Kinerja Karyawan PT. Lamongan Gas Lestari Kabupaten Lamongan?

3. Apakah Total Quality Management dan Keadilan Prosedural (Procedural justice) berpengaruh terhadap Kinerja Karyawan PT. Lamongan Gas Lestari Kabupaten Lamongan?

\section{TUJUAN PENELITIAN.}

Berdasarkan rumusan masalah, maka tujuan yang ingin di capai dalam penelitian ini adalah:

1. Untuk mengetahui dan menganalisa pengaruh Total Quality Managementterhadap Kinerja Karyawan PT. Lamongan Gas Lestari Kabupaten Lamongan.

2. Untuk mengetahui dan menganalisa pengaruh Keadilan Prosedural (Procedural justice) terhadap Kinerja Karyawan PT. Lamongan Gas Lestari Kabupaten Lamongan.
3. Untuk mengetahui dan menganalisa pengaruh Total Quality ManagementKeadilan Prosedural (Procedural justice) terhadap Kinerja Karyawan PT. Lamongan Gas Lestari Kabupaten Lamongan.

\section{KAJIAN PUSTAKA}

\subsection{Pengertian Total Quality Management}

Total Quality Management merupakan pendekatan dalam menjalankan usaha yang mencoba memaksimumkan daya saing organisasi melalui perbaikan terus menerus atas produk, jasa, manusia, proses dan lingkungannya (Tjiptono dalam Candrama, 2011:12).

Total Quality Management (TQM) menurut Hardjosoedarmo (2004) adalah penerapan metode kuantitatif dan pengetahuan kemanusiaan (Meyliana dan Renata, 2012:58) untuk:

1. Memperbaiki material dan jasa yang menjadi masukan organisasi,

2. Memperbaiki semua proses penting dalam organisasi, dan

3. Memperbaiki upaya memenuhi kebutuhan para pemakai produk dan jasa pada masa kini dan di waktu yang akan datang

Total quality management (TQM) is one of the quality-oriented approaches that many organizationsimply. TQM has attracted scholars because of the growing diffusion and acceptance in the business world. Especially over the two decades, TQM is one of the most popular and durable management concepts (Cemal,2012:273)

Sashkin dan K. Kiser menguraikan unsur budaya TQM menurut mereka adalah

1. Kualitas .

2. Tanggung jawab

3. Penghargaan/ Reward

4. Kerjasama

5. jaminan keamanan

6. Keadilan

7. Kompensasi

8. Rasa memiliki organisasi

\subsection{Definisi Keadilan Prosedural}

Menurut Greenberg dan Baron (2003) keadilan prosedural didefinisikan sebagai persepsi keadilan atas pembuatan keputusan dalam organisasi dibuat orang-orang di dalam organisasi sangat memperhatikan dalam pembuatan keputusan secara adil, dan mereka merasa bahwa organisasi dan karyawan akan 
sama-sama merasa diuntungkan jika organisasi melaksanakan prosedur secara adil.

Sedangkan definisi keadilan prosedural menurut Kreitner dan Kinicki (2003) adalah keadilan yang dirasakan dari proses dan prosedur yang digunakan untuk mengalokasikan keputusan (Hasmarini dan Yuniawan, 2008:101).

Indikator-indikator dari keadilan prosedural (Colquitt dalam Muslimin, 2017:37-38) yaitu:

1. Kendali proses

2. Kendali keputusan

3. Konsistensi

4. Bebas prasangka

5. Akurasi informasi

6. Mampu koreksi

7. Etika dan moral

\subsection{Definisi Kinerja Karyawan}

Menurut Prawirosentana, Kinerja atau performance adalah hasil kerja yang dapat dicapai oleh seseorang atau sekelompok orang dalam organisasi, sesuai wewenang dan tanggung jawab masing-masing dalam upaya mencapai tujuan yang legal, tidak melanggar hukum dan sesuai dengan moral dan etika (Sutrisno, 2011:170).

Menurut Seymour dalam Swasto (1996), kinerja merupakan tindakan-tindakan atau pelaksanaan yang dapat diukur. Sedangkan Stoner (1986), mendefiniskan kinerja sebagai kuantitas dan kualitas pekerjaan yang dihasilkan oleh individu, kelompok atau organisasi (Priyono, 2014:185)

Untuk mengetahui kinerja karyawan di perlukan kegiatan-kegiatan khusus. Bernardin dan Russel (1995) (Sutrisno, 2011:179-180) mengajukan enam kinerja primer yang dapat di gunakan untuk mengukur kinerja yaitu:

1. Quality

2. Quantity

3. Timeliness

4. Cost effectiveness

5. Need for supervision

6. Interpersonal impact

\section{METODE PENELITIAN}

\subsection{Rancangan Penelitian}

Desain penelitian yang digunakan dalam penelitian ini adalah metode survey dan metode kuantitatif. Menurut Sugiyono (2014:14) metode survey adalah metode penelitian kuantitatif yang digunakan untuk mendapatkan data yang terjadi pada masa lampau atau pada saat ini, tentang keyakinan, pendapat,karakteristik, perilaku, hubungan variabel dan untuk menguji beberapa hipotesis tentang sosiologi dan psikologis dari sampel yang diambil dari populasi tertentu, teknik pengumpulan data dengan pengamatan kuesioneryang tidak mendalam dan hasil penelitian cenderung untuk digeneralisasikan.

\subsection{Data dan Sumber Data}

Data dalam penelitian ini adalah Data primer, yaitu sumber data yang langsung memberikan data kepada pengumpul data (Sugiyono, 2015:137).Jadi dalam pengumpulan data seorang penulis mendapatkan data melalui observasi atau pengamatan langsung dari perusahaan, baik itu melalui observasi dan wawancara secara langsung dengan pimpinan dan karyawan di PT. Lamongan Gas Lestari Kabupaten Lamongan, sehubungan dengan kebutuhan dalam penelitian ini.

\subsection{Populasi dan Sampel}

1. Populasi

Populasi adalah wilayah generalisasi yang terdiri atas objek/subyek yang mempunyai kualitas dan karakteristik tertentu yang di tetapkan oleh peneliti untuk dipelajari dan kemudian ditarik kesimpulannya (Sugiyono,2015:80). Populasi dalam penelitian ini adalah seluruh karyawan dari PT. Lamongan Gas Lestari Kabupaten Lamongan

2. Sampel

Sampel adalah bagian dari jumlah bagian dari jumlah dan karakteristik yang dimiliki oleh populasi tersebut. Bila populasi besar, dan peneliti tidak mungkin mempelajari semua yang ada pada populasi, misalnya karena keterbatasan dana, tenaga dan waktu, maka peneliti dapat menggunakan sampel yang diambil dari populasi itu (Sugiyono,2015:81).

Sampel dalam penelitian ini adalah sampel jenuh berjumlah 34 karyawan (1 karyawan berhalangan)

3. Teknik Sampling.

Penelitian ini menggunakan teknik pengambilan sampel yaitu Simple Random Sampling yang termasuk dalamProbability 
sampling.Probability sampling adalah tehnik pengambilan sempel yang memberi peluang/kesempatan sama bagi setiap unsur atau anggota populasi untuk di pilih menjadi sampel.Simple Random Sampling adalah di katakan simple karena pengambilan sampe dari anggota populasi di katakan acak tanpa memperhatikan strata yang ada populasi itu (Sugiyono, 2015:82).

\subsection{Tehnik Pengumpulan Data}

Tehnik pengumpulan data yang digunakan adalah Dalam usaha memperoleh data yang dibutuhkan, metode yang digunakan adalah: Kueisoner

Penelitian kueisoner yaitu penelitian yang dilakukan dengan cara langsung ke instansi, untuk mendapatkan data primer melalui penyebaran kuesioner yang dibagikan kepada karyawan perusahaan mengenai Total Quality Management dan Keadilan prosedural terhadap Kinerja karyawan. Responden diminta menanggapi pertanyaan yang diberikan dengan cara menjawab daftar pertanyaan yang ada pada kuesioner.

\section{Skala Pengukuran}

Menurut sugiyono (2015:93) Mengatakan bahwa Skala yang digunakan untuk mengukur sikap, pendapat, dan persepsi seseorang atau kelompok orang tentang fenomena sosial., skala Likert memiliki lima kategori dan nilai atau skor yang dapat diberikan kepada responden diantaranya yaitu:

$\begin{array}{ll}\text { Kategori } & \text { Skor } \\ \text { Sangat setuju(SS) } & 5 \\ \text { Setuju(S) } & 4 \\ \text { Netral(N) } & 3 \\ \text { Tidak setuju (TS) } & 2 \\ \text { Sangat tidak setuju (STS) } & 1\end{array}$

\subsection{Definisi Operasional Variabel}

Definisi operasional merupakan petunjuk tentang bagaimana suatu variabel di ukur, sehingga peneliti dapat mengetahui baik buruknya pengukuran tersebut. Adapun definisi operasional dalam penelitian ini adalah:

1. Total Quality Management (X1)

Mears (1993) mendefinisikan TotalQuality Management sebagai suatu sistem yang di laksanakan dalam jangka panjang dan terus menerus untuk memuaskan konsumen dengan meningkatkan kualitas produk perusahaan (Sutrisno, 2011:91).

Adapun indikator yang digunakan untuk mengukur TotalQuality Management :

1. Kualitas

2. Tanggung jawab

3. Penghargaan/ Reward

4. Kerjasama

5. jaminan keamanan

6. keadilan

7. kompensasi

8. rasa memiliki organisasi

3.7.2 Keadilan Prosedural (X2)

Menurut Greenberg dan Baron (2003) keadilan prosedural didefinisikan sebagai persepsi keadilan atas pembuatan keputusan dalam organisasi dibuat orang-orang di dalam organisasi sangat memperhatikan dalam pembuatan keputusan secara adil, dan mereka merasa bahwa organisasi dan karyawan akan sama-sama merasa diuntungkan jika organisasi melaksanakan prosedur secara adil. (Hasmarini dan Yuniawan, 2008:101).

Indikator-indikator dari keadilan prosedural (Colquitt dalam Muslimin, 2017:37-38) yaitu:

1. Kendali proses

2. Kendali keputusan

3. Konsistensi

4. Bebas prasangka

5. Akurasi informasi

6. Mampu koreksi

7. Etika dan moral

3 Kinerja Karyawan (Y)

Menurut Prawirosentana, Kinerja atau performance adalah hasil kerja yang dapat dicapai oleh seseorang atau sekelompok orang dalam organisasi, sesuai wewenang dan tanggung jawab masing-masing dalam upaya mencapai tujuan yang legal, tidak melanggar hukum dan sesuai dengan moral dan etika (Sutrisno, 2011:170).Adapun indicator yang digunakan untuk mengukur kinerja karyawan:

1. Quality

2. Quantity

3. Timeliness

4. Cost effectiveness

5. Need for supervision

6. Interpersonal impact

\subsection{Analisa data}


Untuk perhitungan penelitian ini menggunakan komputer melalui program SPSS 23.0 for windows. Adapun pengujian penelitian ini digunakan uji:

\section{Uji Validitas}

Uji validitas adalah suatu ukuran yang menunjukkan tingkat-tingkat kevalidan atau kesahihan suatu instrument (Arikunto, 2010:315). Dalam penelitian ini validitas yang digunakan adalah pengujian validitas konstruksi dilakukan dengan analisis factor, yaitu dengan mengkorelasikan antar skor factor dengan skor total dan pengujian validitas isi dapat dibantu dengan mengunakan kisi-kisi instrument, atau matrik pengembangan instrumen. Dalam kisi-kisi itu terdapat variabel yang diteliti, indicator sebagai tolak ukur dan nomor butir (item) pertanyaan atau pernyataan yang telah dijabarkan dari indikator.

Dalam mengukur validitas digunakan rumus korelasi product moment yang dikemukakan oleh Pearson sebagai berikut :Korelasi antara skor item dengan skor total dapat dihitung dengan rumus Product Moment. Tingkat signifikansi ditentukan sebesar 0,05 .

Dengan kreteria pengukuran

a. Apabila rhitung> rtabel (pada taraf signifikansi $5 \%)=$ valid .

b. Apabila rhitung<rtabel(pada taraf signifikansi $5 \%$ ) $=$ tidak valid

\section{Uji Reabilitas}

Uji reliabilitas digunakan untuk menunjukkan bahwa sesuatu instrumen cukup dapat dipercaya untuk digunakan sebagai alat pengumpul data karena instrumen tersebut sudah baik (Arikunto, 2010:239).

Kreteria pengukuran

a. hasil alpha cronbach lebih dari 0,60= reliable

b. hasil alpha cronbach kurang dari $0,60=$ tidak reliable

\section{Analisis Regresi Linier Berganda}

Setelah melakukan uji asumsi klasik lalu menganalisis dengan metode regresi linear berganda dengan alasan variabel bebas terdiri dari beberapa variabel.Analisis regresi linear berganda digunakan untuk mengetahui pengaruh variabelterikat atas perubahan dari setiap peningkatan dan penurunan dari variabel bebas yang akan mempengaruhi variabel terikat. Analisis ini dirumuskan sebagai berikut (Sugiyono, 2008:277).:

Persamaan :

$$
Y=a+\beta_{1} X_{1}+\beta_{2} X_{2}+e
$$

Keterangan :

Y : Penempatan Karyawan

a : Konstanta

$\beta 1, \beta 2$, : Koefisien Regresi

X1 : Total Quality Management

X2 : Keadilan Prosedural

e : Standar eror

\section{Asumsi Klasik}

Uji asumsi klasik digunakan untuk memperoleh hasil/nilai yang tidak bias atau estimator linear tidak bias yang terbaik Asumsi klasik tersebut yaitu :

1). Uji Normalitas digunakan untuk mengetahui apakah dalam model regresi variabel pengganggu atau residual memiliki distribusi normal atau tidak. Salah satu cara termudah untuk melihat normalitas residual adalah dengan melihat grafik histogram yang membandingkan antara data observasi dengan distribusi yang mendekati distribusi normal.

a. Jika data (titik) menyebar disekitar dan mengikuti arah garis diagonal maka model regresi memenuhi asumsi normalitas.

b. Jika data menyebar jauh dari diagonal dan/atau tidak mengikuti arah garis diagonal maka model regrsi tidak memenuhi asumsi normalitas

2.) Uji Multikolinearitas

Uji multikolinearitas bertujuan untuk menguji apakah pada model regresi ditemukan adanya korelasi antar variabel bebas. Untuk mendeteksi ada atau tidaknya multikolinearitas di dalam model regresi adalah dengan Suatu model regresi menunjukan adanya multikolonieritas diantarnya bisa dilihat dari nilai VIF, apabila nilai VIF di bawah angka 10 (NilaiVIF < 10) maka dikatakan tidak terjadi multikolinieritas). 


\section{3.) Uji Heteroskedastisitas}

Uji heteroskedatisitas bertujuan untuk menguji apakah dalam model regresi terjadi ketidaksamaan variance dari residual satu pengamatan ke pengamatan yang lain. Salah satu cara untuk mendeteksi ada atau tidaknya heteroskedastisitas itu dengan melihat grafik plot antara nilai prediksi dengan residualnya, adapun dasar untuk menganalisisnya adalah:

a. Jika ada pola tertentu (bergelombang, melebar kemudian menyempit) maka mengindikasikan telah terjadi heteroskedastisitas.

b. Jika tidak ada pola yang serta titik menyebar diatas dan dibawah angka 0 pada sumbu $\mathrm{Y}$, maka tidak terjadi heteroskedastisitas.

4.) Uji Autokorelasi

Autokorelasi adalah hubungan yang terjadi antara residual dari pengamatan satu dengan pengamatan yang lain. Untuk mendeteksi ada atautidaknya autokorelasi, maka Durbin Watsonakan dibandingkan dengan DW tabel dengan kriteria sebagai berikut:

- Jika DW > 4 maka ada autokorelasi

- Jika DW <4 Maka tidak ada autokorelasi

5. Analisis koefesien determinasi (R2)

Analisis koefisien R2 dilakukan untuk mengukur seberapa jauh kemampuan variabel bebas (independen) menerangkan variasi variabel terikat (dependen).Nilai $\mathrm{R}^{2}$ terletak diantara 0 dan 1 . Jika $R^{2}=1$, berarti garis regresi tersebut menjelaskan $100 \%$ variasi atau proporsi dalam variabel dependen. Maka dapat diarahkan bahwa suatu model dapat dikatakan lebih baik apabila nilai koefisien determinasinya mendekati 1 .

\section{Uji hepotesis}

\section{1.) Uji F atau Uji simultan}

Uji $F$ dilakukan untuk mengetahui signifikansi pengaruh variabel-variabel independen terhadap variabel dependen secara bersama-sama.

Dengan hipotesis :

Ho $: \beta=0$ artinya, tidak ada pengaruh antara variabel bebas secara simultan terhadap penempatan karyawan.

Ha : $\beta>0$ artinya, ada pengaruh antara variabel bebas secara simultan terhadap penempatan karyawan.

Dengan tingkat signifikansi $(\alpha)$ yang digunakan adalah 5\%,distribusi $\mathrm{F}$ dengan derajat kebebasan $(\alpha ; \mathrm{K}-1, \mathrm{n}-\mathrm{K})$.

Kriteria pengujian :
- Fhitung $<$ Ftabel = Ho diterima, artinya variabel independen secara serentak atau bersamaan tidak mempengaruhi variabel dependen secara signifikan.

- Fhitung $>$ Ftabel = Ho ditolak, artinya variabel independen secara serentak atau bersamasama mempengaruhi variabel dependen secara signifikan.

2.) Uji t atau Uji parsial

Pengujian ini pada dasarnya menunjukkan seberapa jauh pengaruh satu variabel independen secara individual dalam menerangkan variabel dependen(Ghozali, 2013: 36).

Dengan hipotesis:

- Ho : b1 =0, artinya tidak ada pengaruh antara variabel independen terhadap variabel dependen - Ha : b1 $=0$, artinya ada pengaruh antara variabel independen terhadap variabel dependen.

Dengan tingkat signifikansi $(\alpha) 5 \%$ dari $\mathrm{df}=\mathrm{n}-\mathrm{K}-1$ diperoleh nilai ttabel, kemudian nilai ttabel dibandingkan dengan nilai thitung yang diperoleh. Dengan membandingkan kedua nilai t tersebut, makaakan diketahui pengaruhnya, yaitu dapat diterima atau ditolaknya hipotesis.

Kriteria pengujian:

- thitung> ttabel Ho ditolak dan Ha diterima, artinya variabel independen mempengaruhi variabel dependen secara signifikan.

- thitung $<$ ttabel Ho diterima dan Ha ditolak, artinya variabel independen tidak mempengaruhi variabel dependen.

\section{HASIL DAN PEMBAHASAN}

\section{1 Uji Validitas}

Uji validitas adalah suatu ukuran yang menunjukkan tingkat-tingkat kevalidan atau kesahihan suatu instrument (Arikunto, 2010:315).

Hasil Uji Validitas perhitungan terlihat pada tabel dibawah ini:

Tabel 5.1 Uji Validitas

\begin{tabular}{|l|c|c|}
\hline NO & $\begin{array}{c}\text { Indik } \\
\text { ator }\end{array}$ & $\begin{array}{c}\text { Corrected Item- } \\
\text { Total Correlation }\end{array}$ \\
\hline 1. & X1.1 & 0.670 \\
\hline 2. & $\mathrm{X} 1.2$ & 0.776 \\
\hline 3. & $\mathrm{X} 1.3$ & 0.748 \\
\hline 4. & $\mathrm{X} 1.4$ & 0.693 \\
\hline 5. & $\mathrm{X} 1.5$ & 0.688 \\
\hline 6. & $\mathrm{X} 1.6$ & 0.574 \\
\hline 7. & $\mathrm{X} 1.7$ & 0.508 \\
\hline 8. & $\mathrm{X} 1.8$ & 0.461 \\
\hline
\end{tabular}




\begin{tabular}{|l|c|c|}
\hline 9. & $\mathrm{X} 2.1$ & 0.811 \\
\hline 10. & $\mathrm{X} 2.2$ & 0.619 \\
\hline 11. & $\mathrm{X} 2.3$ & 0.801 \\
\hline 12. & $\mathrm{X} 2.4$ & 0.788 \\
\hline 13. & $\mathrm{X} 2.5$ & 0.679 \\
\hline 14. & $\mathrm{X} 2.6$ & 0.839 \\
\hline 15. & $\mathrm{X} 2.7$ & 0.772 \\
\hline 16. & Y.1 & 0.587 \\
\hline 17. & Y.2 & 0.678 \\
\hline 18. & Y.3 & 0.594 \\
\hline 19. & Y.4 & 0.622 \\
\hline 20. & Y.5 & 0.560 \\
\hline 21. & Y.6 & 0.717 \\
\hline
\end{tabular}

Sumber: Data primer, 2019 diolah

Dari tabel di atas dapat diketahui bahwa semua indikator yang digunakan untuk mengukur variabel-variabel yang dugunakan dalam penelitian ini mempunyai Corrected Item-Total Correlation lebih besar dari rtabel, artinya semua butir indikator adalah valid karena memiliki rhitung > rtabel $(0,329)$.

\subsection{Uji Reliabilitas}

Uji reliabilitas digunakan untuk menunjukkan bahwa sesuatu instrumen cukup dapat dipercaya untuk digunakan sebagai alat pengumpul data karena instrumen tersebut sudah baik (Arikunto, 2010:239).

Tabel 5.2 Uji Reliabilitas

\begin{tabular}{|c|l|c|}
\hline No & \multicolumn{1}{|c|}{ Variabel } & $\begin{array}{c}\text { Cronb } \\
\text { ach's } \\
\text { Alpha }\end{array}$ \\
\hline 1 & Total Quality Management (X1) & 0.770 \\
\hline 2 & Keadilan Prosedural(X2) & 0.878 \\
\hline 3 & Kinerja karyawan(Y) & 0.713 \\
\hline
\end{tabular}

Sumber : Data diolah SPSS 23, 2019

Dari tabel di atas dapat diketahui bahwa nilai Cronbach Alpha dari seluruh variabel yang diujikan nilainya sudah diatas 0,60 maka dapat disimpulkan bahwa seluruh variabel dalam penelitian ini lolos dalam uji reliabilitas dan dinyatakan reliable

\subsection{Regresi Linier Berganda} bawah ini :

Hasil regresi seperti dalam tabel di

Tabel 5.3 Koefisien Regresi Linier Berganda

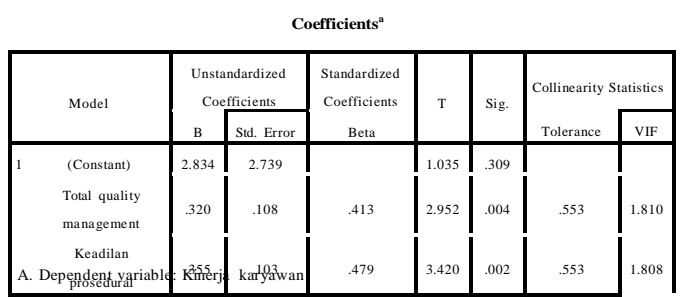

Berdasarkan hasil perhitungan regersi linier berganda pada tabel diatas, didapat suatu persamaan regresi sebagai berikut:

$$
\mathrm{Y}=2,834+0,320 \mathrm{X} 1+0,355 \mathrm{X} 2
$$

Dimana:

$$
\text { (4.1) }
$$

$\mathrm{Y}=$ Kinerja Karyawan

$\mathrm{a}=$ Konstanta

$\mathrm{X} 1=$ Total Quality Management

$\mathrm{X} 2=$ Keadilan Prosedural

Persamaan refgresi dapat dijelaskan sebagai berikut:

1. Hasil konstanta sebesar 2,834 artinya apabila variabel Total Quality Management (X1) dan Keadilan Prosedural (X2) yang mempengaruhi $=0$, maka hasil yang diperoleh darikinerja karyawanadalah sebesar 2,832

2. Hasil koefisien regresi X1 sebesar 0,320, artinya apabila Total Quality Management (X1) meningkat satu satuan, maka akan meningkatkan kinerja karyawan sebesar 0,320 dengan asumsi variabel lain dianggap konstan.

3. Hasil koefisien regresi $\mathrm{X} 2$ sebesar 0,355 artinya apabila keadilan procedural meningkat satu satuan, maka akan meningkatkan kinerja karyawan sebesar 0,355 dengan asumsi variabel lain dianggap konstan.

\subsection{Uji Asumsi Klasik}

1. Autokorelasi autokrelasi:

Berikut ini adalah hasil pengujian

Tabel 5.4 autokrelasi

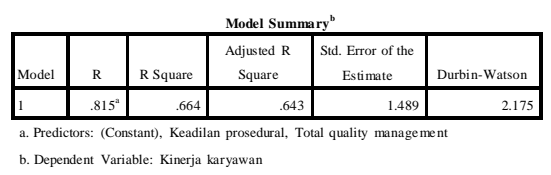

Sumber : Data primer, diolah (2019) (2019)

- Jika DW > 4 - dl, maka ada autokorelasi

- Jika DW < 4 - dl, maka tidak ada autokorelasi

Berdasarkan tabel diatas, di ketahui nilai dari Durbin Watson

4-dl $=4-1,3325=2,6675$

Hasilnya $2,175<2,6675$, artinya tidak ada autokorelasi. 
2. Uji Multikolinieritas

Hasil Uji Multikolinieritas seperti tabel dibawah ini:

Tabel 5.5 Uji Multikolinieritas

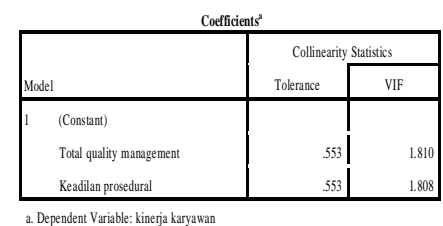

Sumber : Data primer diolah (2019)

Dari hasil analisis di dapat nilai tolerance untuk kedua variabel $=0,553>0,1$ dan $\mathrm{VIF}=1,810<10, \mathrm{VIF}=1,808<10$ maka tidak terjadi multikolinieritas antar variable independennya.

\section{Uji Heteroskedastisitas \\ Hasil Uji Heteroskedastisitas berikut} ini:

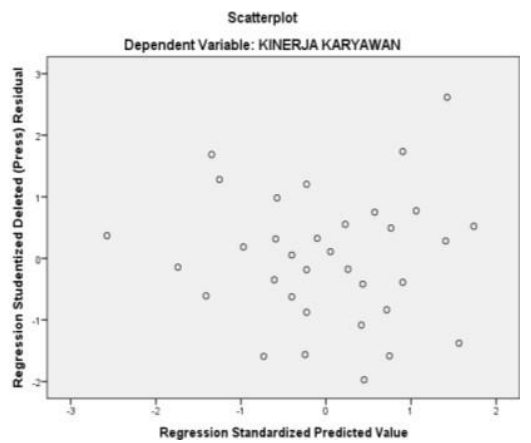

\section{Gambar 5.1 Hasil scatterplot}

Sumber : Data diolah (2019)

Berdasarkan gambar diatas karena pada output scatterplot tidak menunjukkan adanya pola yang jelas, maka tidak terjadi heteroskedastisitas pada data yang digunakan pada model tersebut.

3. Uji Normalitas

Hasil pengujian normalitas dapat dilihat dalam gambar berikut:

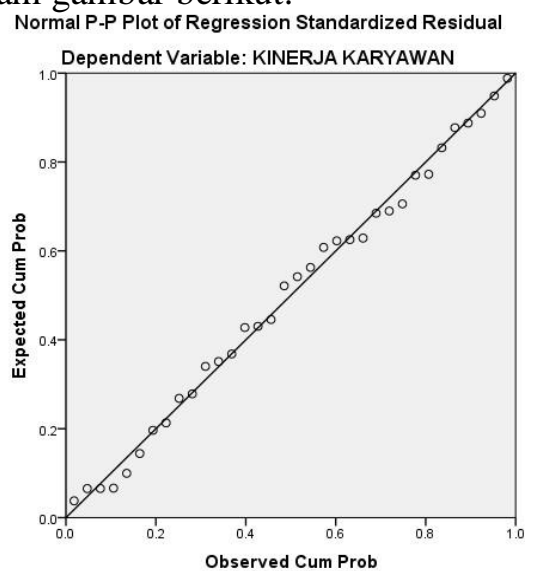

Gambar 5.2 Uji Normalitas

Sumber : Data primer, diolah (2019)

Karena pada Normal P-Plot data (titik) menyebar disekitar dan mengikuti arah garis diagonal maka model regresi memenuhi asumsi normalitas.

\subsubsection{Uji Kofisien Determinasi}

Koefisien determinasi digunakan untuk menyatakan proporsi total variabel dependen yang dapat dijelaskan oleh variabel independen. Nilai $\mathbf{R}^{2}$ terletak diantara 0 dan 1 .

Uji koefisien determinasi seperti tabel dibawah ini :

\section{Tabel. 5.6 Uji determinasi}

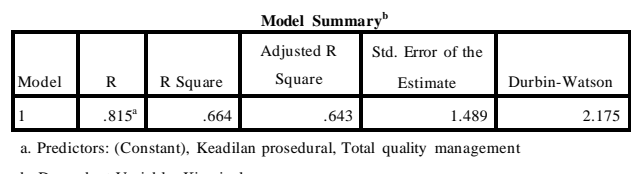

Sumber : Data primer diolah 2019

Nilai koefisien Relasi (R) pada model summary antara variabel Total Quality Management (X1) dan Keadilan Prosedural (X2) terhadap Kinerja Karyawan (Y) adalah 0,815 , berarti hubungan antara Total Quality Management (X1) dan Keadilan Prosedural (X2) terhadap Kinerja Karyawan (Y) adalah sebesar $81,50 \%$. Nilai $\mathrm{R}$ square $\left(\mathrm{R}^{2}\right)$ adalah 0,664 artinya $66,40 \%$ variasi yang terjadi terhadap tinggi rendahnya kinerja karyawan disebabkan variasi Total Quality Management (X1) dan Keadilan Prosedural (X2) sisanya $33,6 \%$ dipengaruhi variabel lain.

\subsection{Uji Hipotesis}

\section{Uji F}

Hasil uji $\mathrm{F}$ seperti dalam tabel di bawah ini :

Tabel 5.6 Hasil Uji F (Test) ANOVA $^{a}$

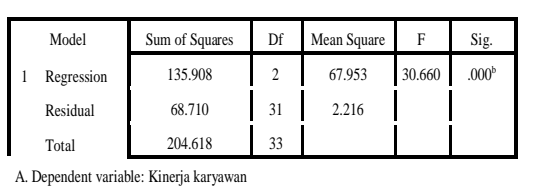

Sumber: Data Primer diolah 2019

Dari uji Anova didapatkan Fhitung = $30.660>$ dari Ftabel $=3,29$, dengan tingkat signifikasi 0,000 karena probabilitas $<0,05$ maka model regresi bisa digunakan untuk memprediksi kinerja karyawan, artinya ada pengaruh variabel Total Quality Management 
dan Keadilan Prosedural secara simultan terhadap kinerja karyawan.

\section{Uji t}

Hasil Uji t sebagai berikut :

Tabel 5.7 Uji T

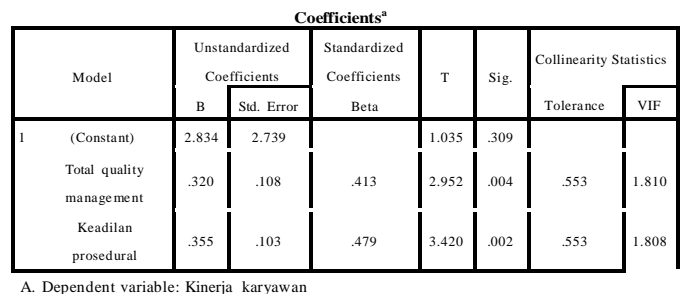

Sumber : Data Primer diolah 2019

Dari hasil hasil analisa diatas dapat dijelaskan sebagai berikut:

Hipotesis 1

Thitung $(\mathrm{X} 1)=2.952>2,04$ dan probabilitas $\mathrm{X} 1=.004<0,05$ maka H1 diterima, artinya ada pengaruh Total Quality Management(X1) terhadap Kinerja Karyawan (Y)

Hipotesis 2

Thitung $(X 2)=3.420>2,04$ dan probabilitas $\mathrm{X} 2=0,003<0,05$ maka $\mathrm{H} 2$ diterima, artinya ada pengaruh variabel Keadilan Prosedural (X2)terhadap Kinerja Karyawan (Y)

\section{SIMPULAN DAN SARAN}

\section{Simpulan}

1. Total Quality Management berpengaruh signifikan positif terhadap kinerja karyawan dengan Sig 0,004 dan R2 = 0,664 . Semakin tinggi tingkat Total Quality Management, maka berpotensi dapat meningkatkan kinerja karyawan..

2. Keadilan Prosedural berpengaruh positif terhadap kinerja karyawan dengan Sig 0,002 dengan R2 sebesar 0,664. Semakin tinggi Keadilan Prosedural karyawan, maka kinerja karyawan juga tinggi.

3. Dari penelitian ini menunjukkan bahwa Total Quality Management dan Keadilan Prosedural berpengaruh terhadap kinerja karyawan sebesar 30,660 dengan Sig 0,000 dan R2 sebesar 0,664. Kedua variabel berpengaruh positif signifikan terhadap kinerja karyawan.

\section{Saran}

Dari hasil penelitian perlu diperhatikan oleh manajemen organisasi yang meliputi :

1. Perusahaan harus memperhatikan Total Quality Management organisasi, organisasi yang mempunyai Total Quality
Management yang baik akan meningkatkan kinerjanya dan akan menguntungkan perusahaan.

2. Manajemen perusahaan harus bisa menjaga dan menumbuhkan kepercayaan terhadap karyawan, agar dalam setiap pekerjaan karyawan berpersepsi perusahaan mengedepankan keadilan dan kesempatan yang sama/keadilan prosedural. Keadilan prosedural yang baik akan mendorong karyawan untuk bekerja dengan baik dan kinerja karyawan akan meningkat.

3. Dari analisis pengaruh Total Quality Management dan Keadilan Prosedural terhadap kinerja karyawan, maka manajemen perusahan dalam pelaksanaan kerjanya diharapkan dapat lebih meningkatkan kualitas dan strategi pengelolaan organisasi dan keadilan terhadap karyawan. Perusahaan juga diharapkan lebih menggairahkan cara kerja karyawan serta memberikan dukungan dan kesempatan yang sama setiap karyawan. Sehingga, diharapkan akan menimbulkan kinerja dari karyawan yang efektif dan efisien

Peneliti selanjutnya diharapkan untuk lebih memperluas ruang lingkup penelitian dan lokasi penelitian serta mengambil sampel lebih banyak sehingga hasil penelitian dapat diimplementasikan secara umum.

\section{DAFTAR PUSTAKA}

A Aburaera, Sukarno, dkk. (2013), Filsafat Hukum: Teori dan Praktek, Cetakan pertama, Edisi Pertama, Kharisma Putra Utama, Jakarta.

Agussalim, M. Ahsan (2017), Implementasi budaya organisasi dalam peningkatan pelayanan administrasi pendidikan di Man 1 Makassar, Skripsi, Fakultas Tarbiyah dan Keguruan UIN Alaudin, Makassar

Arikunto, Suharsimi (2013), Metodologi Penelitian, Suatu Pendekatan Praktek, PT. Rineka Cipta, Jakarta.

Candrama, Kadek Teja (2011), Pengaruh Total Quality Management (TQM), Gaya Kepemimpinan, Kedisiplinan Kerja Dan Fungsi Mentoring Terhadap Kinerja Karyawan Pt. Pos Indonesia, Kantor Pos Yogyakarta, Skripsi, Fakultas Ekonomi, Universitas Pembangunan Nasional "Veteran", Yogyakarta. 
Cemal, Zehir, et.,al. (2012), Total Quality Management Practices' Effects on Quality Performance and Innovative Performance, Procedia - Social and Behavioral Sciences, Vol. 41: $273-280$

Dewi, Ayu Mustika (2010),Pengaruh Budaya Kualitas Pada Kepuasan Kerja, Kinerja, Dan Keinginan Untuk Pindah Dengan Komitmen Organisasional Sebagai Variabel Pemediasi Studi Pada Karyawan Bagian Produksi PT. Tiga Serangkai Pustaka Mandiri Surakarta, Skripsi, Fakultas Ekonomi, Uiveersitas Neegeri Sebelas maret, Surakarta

Ghozali, Imam (2013), Aplikasi Analisis Multivariate dengan Program SPSS 21,Edisi ke-7, B-P UNDIP,Semarang.

Hadi, Amin Prasetyo (2014), Analisis Pengaruh Total Quality Management Terhadap Kinerja Manajerial, Skripsi, Fakultas Ekonomika dan Bisnis, Universitas Diponegoro, Semarang.

Hasanah, Nikmah (2013), Pengaruh Total

Quality Management Terhadap Kinerja

Manajerial Dengan Sistem Pengukuran Kinerja Dan Sistem Penghargaan Sebagai Variabel Moderating (Studi Empiris Pada Staf Akuntansi Perusahaan Jasa Di Wilayah Jakarta Dan Tangerang), Skripsi, Fakultas Ekonomi Dan Bisnis, Universitas Islam Negeri Syarif Hidayatullah, Jakarta.

Hasmarini, Dwi Peni Dan Yuniawan, Ahyar (2008), Pengaruh Keadilan Prosedural Dan Distributif Terhadap Kepuasan Kerja Dan Komitmen Afektif, Jurnal Bisnis Strategi, Vol. 17 No.1 Juli 2008 :99-118

Kirana, Kusuma Chandra dan Ratnasari, Ririn Tri (2015), Evaluasi Kinerja Sumber Daya Manusia (SDM), Cetakan pertama, Edisi pertama, Gosyen Publishing, Yogyakarta.

Kusumohamidjojo, Budiono (2016), Teori Hukum: Dilema Antara Hukum dan Kekuasaan, Cetakan pertama, Edisi pertama, Yrama Widya, Bandung.

Meyliana dan Renata, Agnes Yoan (2012), Pengaruh Total Quality Management pada suatu sistem pengukuran kinerja terhadap pengembangan produk dan efisiensi biaya:study kasus pada PT. Bintang Alam Semesta, Jurnal Akutansi,Vol.4 No.1 Mei: 57-69.

Muslimin, Ahmad (2017), Pengaruh Keadilan Distributif, Keadilan Prosedural Dan
Keadilan Interaksional Terhadap Kepuasan Kerja Pada Karyawan Pt. Pos Indonesia Surakarta, Skripsi, Fakultas Ekonomi Dan Bisnis, Islam Institut Agama Islam Negeri Surakarta, Surakarta.

Perdana, Toga (2012), Analisis Pengaruh

Keadilan Prosedural Dan Interpersonal

Terhadap Task Performance Pada

Karyawan, Serta Peran Mediasi Motivasi Intrinsic ( Studi Kasus Pada Karyawan PT. Krakatau Steel (Persero) Tbk.), Skripsi, Fakultas Ekonomi, Universitas Indonesia, Depok,

Priyono (2010), Manajemen Sumber Daya

Manusia, Cetakan kedua, Zifatama, Sidoarjo.

Solichin (2010), HMI, Candradimuka Mahasiswa, Sinergi Persadatama Foundation, Jakarta.

Sugiyono (2008).Statistika untuk Penelitian. Bandung: Alfabeta. (2014).Statistika untuk Penelitian.

Bandung: Alfabeta.

(2015).Statistika untuk Penelitian.

Bandung: Alfabeta.

Sutrisno, Edy (2011), Budaya Organisasi, Cetakan kedua, Edisi pertama, Kencana Prenada Media Group, Jakarta.

Widiastuti, Rosita Kharisma (2016), Pengaruh Keadilan Prosedural Terhadap Kinerja Karyawan Dengan Tingkat Kepuasan Karyawan Sebagai Variabel Intervening, Skripsi, Fakultas Ekonomi, Universitas Negeri Yogyakarta, Yogyakarta.. 